Motrivivência Ano XXI, No 32/33, P. 156-177 Jun-Dez./2009

\title{
A COPA E A MÍDIA: reflexões sobre a mais-valia ideológica, a soberania comunicacional e o jornalismo
}

Elaine Tavares

\section{Resumo Abstract}

O texto traz uma reflexão sobre a forma como a mídia comercial tem atuado no que diz respeito ao anúncio das benesses da realização da Copa do Mundo no Brasil em 2014. A análise se faz a partir dos conceitos de mais-valia ideológica, proposto por Ludovico Silva, soberania comunicacional, uma construção coletiva dos comunicadores populares venezuelanos e brasileiros, e o jornalismo como forma de conhecimento, proposto por Adelmo

Genro Filho. Parte-se da pedagogia de sedução capitalista, incensada pela mídia, e chega-se a propostas de controle popular soberano e jornalismo libertador.

Palavras-chave: Copa; Mídia; Jornalismo; Comunicação.

The text presents a reflection on how the business press has acted with regard to the announcement of the rewards of holding the World Cup in Brazil in 2014. The analysis is based on the concepts of plus-value ideological, proposed by Ludovico Silva, communication sovereignty, a collective of communicators popular Venezuelan and Brazilian, and journalism as a form of knowledge, proposed by Adelmo Genro Filho. It starts with the pedagogy of seduction capitalist, incensed by the media, and comes to proposals for sovereign control popular and journalism and liberating. Keywords: Cup, Media, Journalism; Communication.

1 Elaine Tavares é jornalista no Instituto de Estudos Latino-Americanos, mestre em Comunicação Social pela PUC/RS e educadora popular. Contato: eteia@gmx.net 
Ano XXI, n 32/33, junho e dezembro/2009

A Copa do Mundo de 2014 começou a ser "vendida" ao povo brasileiro muito antes do início da copa de 2010, na África do Sul. Essa "venda" apareceu e segue aparecendo nas reportagens dos programas de esporte, nos noticiários gerais e até nos programas de entretenimento. $\mathrm{E}$ tudo isso tem uma razão muito simples. A copa não é mais só um espaço lúdico de competição do futebol, em que qual os países disputam uma linda taça de ouro praticando um futebol arte, dançante, alegre. Este evento é um dos mais importantes espaços de venda de mercadorias do mundo, talvez as mais raras e caras: seres humanos com habilidades especiais, ou ainda, para melhor compreensão, os jogadores. Não bastasse isso, ele alavanca a venda de outras tantas milhares de mercadorias que, apenas com a menção do nome "copa", disparam no mercado mundial, tais como camisetas de time, bonés, bandeiras, fitinhas, etc..., além de aquecer o turismo, hotelaria, serviços e comércio de todo tipo. No Brasil já existe até um portal na internet que, desde maio de 2010, divulga todas as notícias que saem nos veículos de comunicação sobre o tão esperado evento.

A cobertura da mídia aos preparativos da Copa 2014 é carregada de ufanismo e boas novas. Quem escuta os repórteres imediatamente vincula o evento a benfei- torias, emprego, alegria, progresso, novas tecnologias. Esses são os pilares de sustentação de uma proposta que, na verdade, ao passar, deixa um profundo e quase irrecuperável lastro de destruição. Mas, então, por que não há um debate crítico na televisão brasileira sobre o que significa verdadeiramente ser a sede de um certame mundial de futebol? Temos algumas hipóteses e vamos procurar refletir sobre elas.

A primeira delas diz respeito à lógica do futebol como mercadoria que, como bem conta o professor Nilso Ouriques no seu livro "A Miséria do Esporte", lançado em julho deste ano pela editora catarinense Insular, começou com a "perigosa" relação entre a FIFA (Federação Internacional de Futebol) e a empresa de material esportivo Adidas, no longínquo 1974. Essa entidade, que era apenas uma pequena federação européia, acaba se transformando ela própria numa megaempresa, uma espécie de multinacional de venda de seres humanos e outras tantas coisas relacionadas ao futebol. O contrato entre a FIFA e Adidas alia a venda de materiais relacionados à prática do esporte, com a negociação de seres humanos, os jogadores, que se transformam também numa mercadoria de alta rentabilidade. $\mathrm{O}$ processo iniciado então chega hoje ao seu mais elevado nível. Tudo é 
negócio. Na verdade, o jogo em si, muito pouco importa. O que vale é o volume de dinheiro que o "evento" envolve e movimenta. Não é sem razão que o evento Copa do Mundo 2014 já tenha começado a gerar lucro, porque, afinal, a roda do capital não pode parar.

Nessa roda viva de promessas de benesses que o evento gera, a mídia faz todo o esforço para potencializar a pedagogia da sedução e manipulação, típica do capitalismo. É por isso, que apesar de ainda faltar tanto tempo para a copa, os programas de televisão já insistem em divulgar as possíveis coisas boas que virão.

Nos programas de esporte é onde se percebe com mais clareza o jogo da "distração", como bem aponta Noam Chomski no texto "As 10 estratégias de manipulação midiática" ${ }^{2}$. As reportagens mostram, de maneira bastante descontraída, como ficarão bonitos os estádios das cidades brasileiras, como serão modernos e funcionais, desviando assim - com textos alegres e ufanistas - a atenção das questões que verdadeiramente importam, como por exemplo, o custo destas obras e o que se poderia fazer pelo esporte comunitário caso essa verba fosse aplicada em projetos desse tipo. No caso do dinheiro gasto para os Jogos Pan-Americanos no Brasil, por exemplo, já se sabe que se fosse usado para criar espaços de prática de esporte e lazer comunitários, poder-se-ia cobrir praticamente todos os municípios do país. Mas, esse acobertamento das questões cruciais relativamente à copa faz parte da proposta de manter o público sempre na ignorância e beirando a mediocridade, para que não possa desenvolver o senso crítico. Como bem já dizia George Orwell, uma opinião pública bem informada é coisa perigosa demais para os poderosos de plantão.

Outra estratégia da pedagogia da sedução capitalista promovida de maneira bastante eficaz pela mídia é mostrar as "belezas" pontuais que a verba usada para a modernização dos estádios trará para as cidades sedes, como se fosse uma espécie de redução de danos, mas que soa sempre como a última maravilha do mundo. É o caso de uma reportagem sobre os ônibus ecológicos que serão colocados em circulação no Rio de Janeiro. Diz a repórter que, durante a copa, circularão ônibus da mais alta tecnologia, movidos parte por

2 Este texto pode ser encontrado na Rede Mundial de Computadores no endereço: http://blog. controversia.com.br/2010/07/31/chomsky-e-as-10-estratgias-de-manipulao-miditica/ 
Ano XXI, n 32/33, junho e dezembro/2009

diesel e parte por energia elétrica, reduzindo em mais de $30 \%$ o consumo de combustível. O tom da notícia é ufanista e alegre, como se a jornalista falasse com crianças. "Vai ser um gol de placa". Nenhuma informação sobre o número de linhas, os bairros que ganharão os ônibus, os roteiros etc... Na verdade, o tal ônibus deverá ser usado apenas para levar e trazer as delegações, já que se trata de um lançamento ainda não usado em grande escala. Possivelmente, acabada a copa, os ônibus desaparecerão da cidade, que seguirá com todos os transtornos atuais do transporte público nas grandes cidades.

Por isso é espantoso ver a alegria com que os repórteres falam dos números que serão gastos na Copa. Até agora, o governo já acenou com a possibilidade de injetar nas "obras da copa" mais de 23 bilhões de reais, mas é bem possível que estas cifras aumentem ainda mais. Ninguém explica que serão necessários empréstimos a juros altíssimos, e que o uso destes valores implicará em redução de investimento em áreas estratégicas como a educação, a saúde, a segurança. O setor hoteleiro, por exemplo, receberá mais de um bilhão. Dinheiro público sendo usado de forma privada, sob a alegação de que é para melhor atender ao turista. Fala-se com a boca cheia que

86 projetos de infraestrutura serão criados em 12 cidades. Ótimo! E as demais cinco mil cidades? Sobre essas, silêncio.

Da mesma forma aparecem matérias falando das linhas de metrô que serão criadas, novos hotéis que serão construídos, modernização das frotas de táxi, ampliação de aeroportos e outras tantas maravilhas que, no frigir dos ovos, não representam muita coisa no universo das monumentais obras que serão feitas nos estádios, que, na verdade, devem consumir a maior parte dos recursos. Esses ficam depois para uso dos clubes, e nada mais que isso, de certa forma privatizando um dinheiro público. Assim, o povo paga por um lugar onde possivelmente nunca porá os pés. No caso dos jogos da copa, muito menos, pois os ingressos são caríssimos, e quem acaba fruindo são os turistas ricos do Brasil e de outros países. Passada a copa, os brasileiros comuns ainda terão de pagar muito mais caro pelos ingressos nos jogos normais, como tem acontecido em vários países que investiram horrores na "modernização" dos estádios. Isso quando eles não se transformam em elefantes brancos, sem serventia para nada.

Mas, na grande imprensa comercial, essas informações sobre como ficaram os países que passaram 
por projetos semelhantes, não aparecem em lugar algum. Um caso bastante flagrante é o da Grécia, que atualmente vive nas telas de TV como um lugar onde se vive uma grande crise. $\mathrm{O}$ que ninguém diz, em meio às imagens de confrontos com a polícia, que parecem brotar do nada, é que muito desta crise grega - que hoje abala toda a Europa - começou antes de 2004, quando o governo arrebanhou nove bilhões de euros em empréstimos para "modernizar" os estádios para as Olimpíadas de 2004 e, de quebra, realizar outras benfeitorias nas cidades. Os anos se passaram, a dívida começou a ser cobrada e os gregos não têm como pagá-la, tamanha bola de neve se formou entre juros e mais juros. Isso sem contar que as tais benfeitorias não apareceram. Agora, o governo pede ao povo que "faça o sacrifício" de reduzir salários, aumentar a idade para a aposentadoria e reduzir as pensões. Ora essa, e todas as belezas que tinham sido anunciadas com o dinheiro das Olimpíadas? Silêncio total!

\section{A televisão como espaço da mais-valia ideológica}

Toda essa algaravia que se vê na imprensa comercial e que tentamos em breves pinceladas mostrar, no que tange à pedagogia de sedução sobre um investimento que vai beneficiar apenas a alguns, foi muito bem analisada por um original pensador venezuelano chamado Ludovico Silva ${ }^{3}$. Discutindo questões como a ideologia e buscando compreender como ela aparecia no cotidiano e com tamanha força que conseguia manter cativas as mentes, ele verificou que a televisão desempenha um papel fundamental na disseminação da ideologia capitalista. Marxista, ele buscou nas categorias do pensador alemão, os instrumentos para analisar os tempos atuais. Segundo Marx, a ideologia é uma formação social, algo que ocupa um lugar preciso dentro da sociedade, uma realidade subjetiva que se determina pela estrutura material dessa sociedade. Desde aí chegou ao conceito de mais-valia, esta como uma realidade concreta, material e mensurável que explica a força de trabalho como uma mercadoria. Assim, Ludovico, unindo a idéia de uma realidade subjetiva (a ideologia) e a realidade concreta (a mais-valia) Ludovico cunhou o conceito de mais-valia ideológica.

A mais-valia ideológica é, para Ludovico Silva, a matéria prima da televisão. Ele chegou a isso se colocando a seguinte questão:

3 Silva, Ludovico. La plus valia ideológica. Universidad Central da Venezuela: Caracas, 1977 
Ano XXI, n 32/33, junho e dezembro/2009

levando em conta a afirmação de Marx de que as relações de produção se reproduzem no plano da ideologia, não seria possível pensar que, assim como na oficina material capitalista se produz a mais-valia, na oficina de produção espiritual, subjetiva, se produziria uma mais-valia ideológica? E que essa mais-valia ideológica serviria para fortalecer e enriquecer o capital ideológico do capitalismo, que por sua vez tem como objetivo proteger e preservar o capital material?

A resposta ele apresenta no seu livro "A mais-valia ideológica", editado em 1977. Para Ludovico Silva, os meios de comunicação de massa, com mais força a televisão, seriam o espaço da mais completa expressão dessa mais-valia que se produz na mente do ser que está exposto ao bombardeio sistemático dos meios. O capitalismo precisava de um instrumento para justificar-se perante os homens, e os meios massivos de comunicação vieram bem a calhar, pela sua capacidade de penetração. Segundo ele, a televisão é verdadeiramente uma extensão do mundo material do trabalho, e um homem ou uma mulher, sentados diante da telinha, seguem absolutamente conectados ao processo produtivo. Seja no intervalo das propagandas, que nada mais são do que a ideologia agindo de maneira voraz, ou nos programas de entretenimento, novelas e de notícias. Tudo está eivado de ideologia. "É um mundo de escravos sem amos, via mais-valia ideológica", diz. "A mente do homem está cheia de valor de troca. A força de trabalho espiritual se mercantilizou, se fez mercadoria e o homem médio do capitalismo não vê em sua força espiritual de trabalho um valor de uso, mas sim um valor de troca" (Silva. Ludovico. La plus valia ideológica.1977, p. 208).

Ludovico chama de "indústria ideológica" o que a escola de Frankfurt cunhou como "indústria cultural", porque, segundo ele, o que menos essa indústria comunicacional produz é cultura, a menos que se veja o homem como um espaço de "cultivo" e aí, no caso, é nada mais, nada menos, do que um cultivo ideológico. Ele observa que uma criatura diante da televisão está usando sua energia mental como um valor de troca, daí ser este um espaço de produção da mais-valia ideológica. Tudo virou mercadoria, até o pretenso momento de lazer ou de entretenimento de quem está na sala de sua casa. Ao interagir com o mundo da produção que salta da telinha, aquele que descansa, na verdade não descansa, segue produzindo para o capitalismo no plano da energia mental.

O pensador venezuelano também destapa o óbvio (sempre tão difícil de ser visto) e mostra que 
a indústria dita cultural é completamente dependente da indústria em geral e, da mesma forma que a indústria concreta escraviza o ser pelo trabalho, a televisão e os meios de comunicação escravizam as consciências. O mundo que os meios apresentam aos seres humanos é o reino das mercadorias, daí a quase impossibilidade de se sair da alienação.

No que diz respeito ao nosso tema, a Copa do Mundo, este conceito é bastante eficaz. Durante as reportagens que abundam nos programas esportivos - aparentemente espaços de entretenimento - além das falsas promessas que aparecem como maravilhas, todo o material noticioso está conectado com a venda de produtos. É o álbum de figurinhas, são as camisetas dos times, é o mascote da copa que vira chaveiro, os bonecos dos jogadores, enfim, todo um universo de produtos e mercadorias que aprisiona o espectador e faz com que ele perceba o momento da Copa como um momento único para fazer compras. Nos intervalos dos programas tudo aponta para isso. Promoções de celulares, televisão e até fogão. A Copa passa ser motivo para a troca de diversos equipamentos, mesmo aqueles que não têm qualquer relação com a competição. É porque, no fundo, o que verdadeiramente importa é a venda de mercadorias. Como bem diz Ludovico: é o capitalismo se justificando perante os homens e mulheres. A Copa é só uma filigrana neste universo de compras.

\section{Fortalecimento de arquétipos e de preconceitos}

Dentro do processo de produção de mais-valia ideológica à qual os "consumidores" dos meios de comunicação ficam submetidos em tempos de Copa do Mundo ou Olimpíadas, também há que se salientar outro elemento importante na concepção capitalista da organização da vida, que é o da competição. Há um fortalecimento da idéia de que o esporte é apenas isso: competição, espaço onde só os fortes são vencedores. Os atletas são mostrados como aqueles que superam todas as agruras de treinamentos intermináveis, uma espécie de super-homens ou mulheres, gente que vence os mais incríveis desafios apenas com a força bruta da sua vontade. $\mathrm{O}$ alto rendimento é elevado à última potência. Esses aparecem como os que devem ser imitados, os exemplos a serem seguidos. Por isso são freqüentes as reportagens mostrando as histórias de superação dos mais diferentes atletas. Quem não se lembra da pequena Daiane dos Santos, chorando de dor, mas realizando sua mais bela performance, aparentemente vencendo todas as barreiras? Ou $\mathrm{O}$ 
Ano XXI, n 32/33, junho e dezembro/2009

Ronaldinho, com o joelho estourado, mas cumprindo sua missão de defender a camisa verde-amarela? Ou Kaká, igualmente destruído, mas ainda assim entrando no gramado e defendendo a pátria? Tudo descrito com a boa e velha dose de emoção, capaz de levar o espectador às lágrimas e pensar que aqueles são os heróis nacionais.

Por outro lado, estes mesmos jornalistas que usam da emoção para repassar essas idéias de dedicação e amor ao esporte, são incapazes de, anos mais tarde, mostrar ao grande público o que foi feito destes atletas. Gente que com pouco mais de 20 anos já está completamente destroçada, incapaz de levantar um balde, por conta do exagerado rendimento que lhe foi exigido ao longo da vida de atleta. Não há reportagens mostrando como termina todo esse processo esportivo que aposta no alto rendimento e alta competitividade. Estas histórias, de dor, de destruição corporal, ficam embaixo do tapete. Não servem para incensar a alegre ciranda das competições esportivas.

Também nestas competições mundiais a mídia - e todo o processo da maquinaria ideológica do capital - aproveita para reforçar preconceitos já estabelecidos.
Um exemplo bem claro disso é a rixa que existe entre argentinos e brasileiros. Nesta última Copa, que aconteceu na África do Sul, isso ficou bastante claro. Propagandas mostravam os argentinos representando arquétipos já bem conhecidos. Algumas chegavam ao grotesco. Uma falta de respeito com esse bravo povo que é nosso irmão, a considerar a grande pátria latinoamericana. Mas, afinal, o que nos distancia dos argentinos? Por que há essa rivalidade? Quais as origens históricas desta rixa, no mais das vezes incompreendida pela maioria das gentes? Ninguém sabe, ninguém diz. Não importa. O que vale mesmo é reforçar esse preconceito, para que num momento qualquer, quando for necessário ao capital, esse ódio possa ser usado, como, por exemplo, aconteceu na Guerra do Paraguai, em 1864. Conforme estudos realizados pelo professor Mauro César Silveira ${ }^{4}$, que estudou as caricaturas feitas sobre a guerra, a mídia tanto retratou o presidente Solano Lopez como um sanguinário ditador que nunca pareceu haver dúvidas da necessidade de destruir o Paraguai e toda "aquela maldade". Ora, esse perfil de sanguinário foi uma construção ideológica, orquestrada e eficaz, que permitiu ao povo

4 Silveira, Mauro César. A Batalha de Papel - A guerra do Paraguai através da caricatura. LPM Editores: Porto Alegre, 1996 
brasileiro vibrar com a "vitória" da guerra, que, na verdade, significou a destruição quase completa do povo paraguaio. Tudo isso apenas para reafirmar o poder da Inglaterra naquele então. Estes elementos históricos são importantes para que se possa pensar o hoje e todo esse bombardeio ideológico, reforçador de preconceitos, que aparece com muita força nas competições esportivas.

Isso mostra que o esporte muito pouco serve para elevar ideias como solidariedade, cooperação, alegria, companheirismo, partilha. Na verdade, é um espaço selvagem do "salve-se quem puder", em que os atletas muito menos do que se superarem buscam superar os demais. É o reino da competição. E o que torna tudo ainda mais sombrio é que este processo todo é patrocinado por megaempresas, que usam esses atletas para unicamente vender seus produtos. Tudo não passa de um jogo de negócios. E todo lucro ao capital.

\section{Transcender a mais valia- ideológica}

Não é novidade para ninguém o poder da mídia como espaço de persuasão e manipulação. Mas, igualmente se sabe que as pessoas, apesar de bombardeadas diariamente com essas informações que buscam preservar "a beleza" do capitalismo, têm um espaço de subversão que é a tomada de consciência do engano, o desmascaramento da ideologia. Isso pode acontecer com o aporte de outras informações via outros meios de comunicação. Hoje, com o advento da internet, isso ficou possível. A rede mundial de computadores abriga uma infinidade de informações anti-sistêmicas e anticapitalistas. Basta que as pessoas aprendam a encontrá-las, o que também não é coisa fácil. De qualquer forma, é importante se ter claro que o problema da mais-valia ideológica não é o dos meios em si, eles apenas reproduzem uma ideologia que sustenta o sistema capitalista. Por isso, o desafio histórico dos movimentos sociais é fazer com que esses meios mudem de mãos e possam oferecer à maioria das gentes não uma ideologia, mas um espaço de construção de consciência de classe.

O esporte, nos meios massivos de comunicação, sempre aparece como um espaço mais elástico, em que os jornalistas podem ser mais informais, fazer reportagens engraçadas, alegres. Isso nada mais é do que o grande golpe da manipulação. Desvelar isso, destapar, descortinar, esse é o grande desafio. Compreender o que se esconde por trás do discurso da competição, do alto rendimento e das melhorias estruturais eleva o senso crítico e 
Ano XXI, n 32/33, junho e dezembro/2009

forma pessoas capazes de transcender à armadilha da produção ininterrupta de mais-valia, seja ela material ou psicológica.

\section{A proposta de soberania co- municacional}

No campo da comunicação muitas são as propostas para realizar esse passo de transcendência, que tire o espectador das redes de sedução do capital. A primeira delas, bastante discutida durante o processo de construção da Primeira Conferência Nacional de Comunicação (Confecom) - que aconteceu em dezembro de 2009 - é avançar para o que os venezuelanos, na sua caminhada de transformação, chamam de "soberania comunicacional". Acreditamos que a proposta apresentada pela maioria dos lutadores sociais do campo da comunicação de "democratização" dos meios, não seja suficiente. E por quê? Porque falar de democratização pressupõe uma anterioridade: discutir de forma muito clara o que vem a ser esse conceito. O que significa democratizar a comunicação no bojo de um Estado capitalista, em que o mando efetivamente não está na mão dos legisladores ou do governo federal? Como democratizar um campo de ação de um Estado que é dirigido, em última instância, pelo capital monopólico? Responder a estas questões é fundamental para que possamos perceber os limites da luta por "democratização" e também as possibilidades que surgem ao debater outra forma de ser Estado, no sendero de outros povos que estão fazendo esse movimento hoje, em países como a Venezuela, a Bolívia e o Equador.

Lenin lembra muito bem no seu texto $A$ revolução proletária e o renegado Kautsky: "É sempre muito natural para um liberal falar em democracia em geral. Mas um marxista nunca se esquecerá de colocar a questão: para que classe?" Porque Lenin sabia muito bem que a democracia tem vários matizes e ela nunca de fato existiu na sua forma pura. Sempre há que se observar o adjetivo. Democracia liberal, democracia burguesa, democracia participativa. Isso nos coloca outra questão: quando falamos em democracia na comunicação, qual é o adjetivo que a acompanha? Ou qual perspectiva de classe a que estamos apontando?

\section{Controle Social}

Uma das propostas que estão na mesa é a do controle social dos meios de comunicação. Olhando assim soa bem. Mas o que significa? Que quem controlaria o setor seria o povo? O que é esse controle social? Quem faria parte de uma Câmara, ou Conselho, 
quem definiria as políticas públicas da comunicação? Aí voltamos a refletir sobre o Estado que temos. $\mathrm{E}$, para isso, basta que passemos os olhos pela conformação da própria Conferência Nacional. Quem foi maioria ali? A quem representavam? O Estado brasileiro se notabiliza por estar a serviço das grandes multinacionais, dos oligopólios, dos monopólios e, na Confecom, estas fatias do setor se manifestaram. Foi até pior, pois os próprios movimentos sociais quiseram a participação do empresariado, "para saber o que eles pensam", como alegou uma diretora da Federação Nacional dos Jornalistas, Valci Zucoloto. Ora, será possível que os que militam por uma outra comunicação não saibam ainda o que pensam os empresários? Acreditam eles que é possível "democratizar" em parceria com o empresariado? Para nós, esta é a velha fórmula da composição de classe que nunca acaba bem para a maioria das gentes.

Para pensar a proposta de controle social democrática apresentada por grande parte dos participantes na Confecom pode-se buscar um bom exemplo no setor de Saúde. Os Conselhos de Saúde municipais e estaduais buscam concretizar essa "democratização" e há muitos lutadores sociais sérios envolvidos, fazendo o embate cotidianamente. Mas, qualquer um que já tenha participado de um ConseIho (e eu já participei) sabe dos limites estreitíssimos deste processo. Avança-se um passo e voltam-se cinco. A maioria dos conselheiros está bem afinada com o status quo e a batalha é quase insana. Bom, mas não há avanços? Sim, há. Pouquíssimos. Mas o que tratamos de fazer aqui é apontar os limites. Não dá para acreditar que o simples estabelecimento de uma lógica de controle social da comunicação possa mudar a forma de organização da mídia comercial que aposta, e muito bem, na manipulação e na mais-valia ideológica. Até porque os conselhos são consultivos. Eles apontam caminhos que podem ou não ser acatados pelos governos.

\section{O Estado democrático brasi- leiro}

Ruy Mauro Marini tem um texto no qual sistematiza o modo de operação de um estado contrainsurgente, típico dos tempos da ditadura. Ele mostra como as ditaduras na América Latina fizeram parte de um projeto dos Estados Unidos na luta contra o socialismo. E fala da doutrina da contra-insurgência, que apresentava os seguintes pontos: aniquilamento dos inimigos (os comunistas), conquistas de bases sociais e institucionalização. Tudo isso foi encaminhado aqui nesta parte do 
Ano XXI, n 32/33, junho e dezembro/2009

continente e aí está a história para comprovar.

Naqueles dias, de 1959 em diante, depois do triunfo da Revolução Cubana, esta foi a doutrina que balizou o poder nos Estados latino-americanos. Além disso, durante esse processo, aconteceram mudanças econômicas e políticas importantes na periferia do capitalismo. O sistema de produção da burguesia nacional se alia ao imperialismo e surge um Estado no qual a preocupação maior era olhar apenas para os interesses do capital monopólico nacional e estrangeiro. Este Estado também passa a usar o exército como a força bruta que travava e impedia a ação dos movimentos sociais. É, no dizer de Marini, o Estado corporativo burguês monopólico.

Depois, com a mudança de política dos EUA, vem a famosa "democratização", na qual a proposta era a transição lenta e gradual para um tipo de estado que apresentasse uma democracia viável. E o que isso quer dizer? Que poderia haver uma abertura política, mas com a manutenção de alguns mecanismos que garantissem o não crescimento dos movimentos sociais e a impossibilidade do socialismo.

E foi o que se viu. O regime abriu, vieram as eleições diretas, o povo pode votar, os partidos vieram à luz, o parlamento se reorganizou, mas, concretamente, várias formas de controle foram renominadas e reinventadas, evitando movimentos de transformação.

Vamos pensar. O parlamento, democraticamente eleito de quatro em quatro anos, representa quem? Quantos lá dentro verdadeiramente representam os interesses das gentes brasileiras? Numa queda de braço entre os interesses do povo e os da elite nacional, dentro do parlamento, quem ganha? Qual o controle que o povo tem destes senhores e senhoras? E sobre as inúmeras maneiras de amortecimento da luta social, o que se pode falar? No governo de Luis Inácio, particularmente, tivemos uma revoada de lideranças sociais e sindicais que abandonaram a radicalidade revolucionária para caminhar sob o domínio da cartilha da política palaciana. Silêncio sobre o agronegócio, sobre a ação das multinacionais, sobre a ocupação do Haiti, sobre os monopólios midiáticos. Aprovação da intervenção do Estado e dos empresários na organização das lutas sindicais. Houve um amortecimento das grandes lutas.

E os poucos que ainda se insurgem contra a ordem dos monopólios, do capital financeiro e contra a superexploração recebem o quê? O braço armado da lei. São presos e criminalizados. A luta social vira caso de polícia, como 
nos anos 60 era caso de segurança nacional. Então, percebem? Mudou o nome e o perfil da força bruta, mas ao que parece a doutrina de contra-insurgência inventada pelos EUA ainda segue vigente. Trata-se de aniquilar o inimigo, vencer todas as suas forças e manter o sistema azeitado para que as multi, mega, trans empresas sigam dominando.

\section{Soberania comunicacional}

Temos clareza de que o processo desatado pela Conferência Nacional de Comunicação foi importante. Os debates que ali se realizaram puderam, inclusive, comprovar, grande parte da análise desenvolvida aqui. Foi fundamental que os lutadores sociais pudessem descerrar alguns véus, pois não há espaço para ingenuidade na luta política. Por outro lado, também ficaram claros todos os limites, os empecilhos, as impossibilidades. Categoricamente não há como falar em democratização enquanto perdurarem os monopólios comunicacionais. Por isso, é mais do que necessário encontrar outros mecanismos de avanço e mudança. $\mathrm{E}$, quando falamos em avanço, não dizemos de melhoria de um estado de coisas que é ruim e que "frankstenianamente" poderia apresentar uma ou outra faceta democrática.
A proposta que apresentamos é da luta por soberania. Como muito bem já apontou o genial Ruy Mauro Marini "falar em democracia é falar de autodeterminação". Ou seja, a democracia que almejamos deve atender as exigências da maioria do povo e não de um pequeno grupo dominante. Ela tem o recorte de classe e pressupõe um Estado cujo povo seja soberano e, por conta disso, possa transferir soberania ao Estado para que este seja independente de fato. Daí nossa consigna ser "por soberania comunicacional" e não apenas a democratização dos meios.

A democracia, se pensada dentro dos marcos da democracia burguesa, significa apenas a possibilidade de uma maior variedade de oferta, avançando um pouco no controle social, sempre com minoria. Já a soberania comunicacional pressupõe uma democracia radical, participativa, em que a participação seja direta e as pessoas possam efetivamente partilhar das decisões acerca do que se ouve, se lê e se vê neste país. Soberania na comunicação significa não arranjar esse modelo que aí está, mas construir, coletivamente, outro modo de comunicar. Esse é um processo muito mais comprometido e radical e, acreditamos, é para ele que devemos avançar.

A idéia de soberania comunicacional expressa justamente a 
Ano XXI, n 32/33, junho e dezembro/2009

questão do direito real à comunicação, não só a receber a informação, como controlar-la e produzi-la, fugindo deste sistema que só suga a mais-valia ideológica da maioria da população. Isso coloca também um embate junto à categoria dos jornalistas. A ênfase na produção de comunicação popular tem levado muitos jornalistas a questionar o fato de gente sem habilitação produzir vídeos, rádio e até material gráfico. Esse é um debate intenso, principalmente na Venezuela, onde o conceito de soberania comunicacional tem caminhado com mais concretude. Mas, aí, também é bom que as pessoas separem o direito de comunicar da técnica do jornalismo. Veículos como jornal, televisão, rádio e internet, apesar de terem muito espaço jornalístico, não são feitos só de jornalismo. Uma novela é uma forma de comunicação, um programa de variedades é uma forma de comunicação, uma conversa com pessoas é uma forma de comunicação, vídeos feitos para narrar a reprodução da vida nas comunidades, as festas, os costumes, são outras formas de comunicar. Não são necessariamente jornalismo. O jornalismo é um jeito de narrar que pressupõe análise, conhecimento histórico, impressão, focos narrativos, contexto, conhecimento sobre linguagem, signos, etc...
De qualquer forma, para além das lutas corporativas que também são necessárias, a população precisa saber que discutir soberania comunicacional é, em última instância, debater soberania em todos os níveis, avançando, fundamentalmente, para outro tipo de estado, socialista, até que o fim de todas as classes nos permita entrar num outro período civilizacional.

\section{E a vida prática?}

Mas, construir essa soberania na comunicação e nas demais instâncias da vida do país não é coisa que se faça por meio de mágica. É preciso trabalho real, na vida mesma, nas comunidades, juntos aos movimentos sociais, porque a sede da soberania, como bem ensina Enrique Dussel, é o povo organizado. Isso significa que muitos dos engravatados que andam por aí a debater democracia, nos inumeráveis encontros em salões acarpetados, precisam voltar a atuar na base, na caminhada diária junto aos estudantes de comunicação, aos lutadores sociais. É preciso que se estude a realidade, a condição do Estado, as forças que estão em combate. É preciso conhecer os limites da nossa ação e sermos capazes de ultrapassá-los, sempre na senda da construção de um país soberano de fato, livre das amarras do capital, no 
qual seja verdadeiramente possível um controle social que atenda as exigências do povo em sua maioria. Isso significa trabalho, muito trabaIho. Há que começar. Até que aconteça aquilo que diz Fidel: a hora em que "el pueblo crea en el pueblo y todo empiece a cambiar".

\section{Um jornalismo de libertação}

Se o campo da comunicação é vasto e abrange vários aspectos do conhecimento, aquele que é o nosso foco de análise neste breve texto é basicamente o jornalismo. É a partir das matérias, notícias, reportagens, crônicas e opinião que a sociedade vai assimilando todas as "mentidas e enganos" da beleza que pode vir a ser o país sediar uma Copa do Mundo. Já observamos, no início deste texto, como os programas jornalísticos acabam por fortalecer e visão do sistema capitalista, sem oferecer ao espectador/leitor/ouvinte os contextos e a historicidade. Nesse sentido, além de estabelecer a luta pela soberania comuniciconal, que é o povo mesmo assumindo o controle dos meios, também é necessário se pensar a produção do jornalismo sob outro olhar. Nesse campo, talvez ninguém tenha conseguido proposta do que o gaúcho Adelmo Genro Filho. No seu livro
"O Segredo da Pirâmide" (1987), ele provoca a demolição da idéia do jornalismo como unicamente manipulador e ideológico, resgatando nele a sua dimensão revolucionária e destacando a capacidade do olhar crítico de cada leitor/espectador, fugindo assim da visão pessimista/ elitista da crítica até então efetuada na vereda frankfurtiana, que via a Indústria Cultural como um processo inelutável.

O trabalho de Genro Filho se faz num momento único da conjuntura brasileira. O Brasil vivia, no início dos anos 80, o fim do regime militar. As grandes manifestações pela anistia incendiavam o país, os exilados voltavam para casa e uma onda de esperança começava a crescer. A nova sociedade já não era mais um sonho distante, acalentado nos calabouços ou nos aparelhos. $\mathrm{O}$ socialismo, então, aparecia como algo possível de ser real. A campanha pelas eleições diretas começou forte e, mesmo ocultada pela grande mídia, foi crescendo. As ruas eram o espelho da realidade e a mídia comercial não mais conseguia esconder a sofreguidão que tomava conta de todos. Emendas no Congresso, passeatas, manifestações de milhares de pessoas. $\mathrm{O}$ gigante adormecido parecia despertar, e mesmo com a frustração de mais uma eleição indireta para o primeiro presidente civil, depois de quase 30 
Ano XXI, n 32/33, junho e dezembro/2009

anos, esse era o caldo efervescente que agitava o país. A morte de Tancredo Neves e a investidura de José Sarney no cargo de presidente não esgotaram a força do sonho. É nesse contexto de esperanças e utopias que Adelmo Genro Filho produz seu pensamento mais original.

Além de fazer uma revisão crítica das tentativas genéricas de teorização sobre a comunicação, nas quais o jornalismo aparece como um apêndice, ele propõe uma teoria específica para o jornalismo, ancorada na idéia de uma sociedade diferente, livre das amarras do capital. Ao contrário do que pregam outros autores, ele não aposta ainda no fim do jornalismo, mas sim na sua capacidade de revolucionar e de caminhar criticamente rumo ao socialismo. Dentro de certos parâmetros, diz ele, que vão do singular ao universal, o jornalismo não precisa ser necessariamente manipulativo. Mesmo na sociedade capitalista, ele apresenta brechas que podem levar o leitor/espectador a pensar sobre o que está vendo e caminhar para uma mudança.

Genro Filho acreditava que era preciso dar um salto, sair dos manuais técnicos e das críticas puramente ideológicas que se faziam ao jornalismo. Por isso, se propôs a pensar o jornalismo como uma forma de conhecimento, centrada no singular, condicionada pelo capita- lismo, sim, mas com potencialidades que ultrapassam a funcionalidade desse meio de produção.

Um enfoque verdadeiramente dialético-materialista deve buscar a concreticidade histórica do jornalismo, captando, ao mesmo tempo, a especificidade e a generalidade do fenômeno. Deve estabelecer uma relação dialética entre o aspecto histórico-transitório do fenômeno e sua dimensão histórico-antológica. Quer dizer, entre o capitalismo (que gestou o jornalismo) e a totalidade humana em sua autoprodução. Dito de outro modo, o jornalismo não pode ser reduzido às suas condições de gênese histórica, nem à ideologia de classe que o trouxe à luz. Parafraseando Sartre: a noticia é uma mercadoria, mas não é uma mercadoria qualquer (Genro Filho, 1987, p. 27).

Ele faz uma crítica ácida da visão funcionalista, que dá ao jornalismo uma função social, mas unicamente voltada ao aperfeiçoamento das instituições democráticas (leia-se status quo) ou à denúncia das patologias sociais, fazendo crer que o que acontece de errado na sociedade perfeita do capital é só um cancro que, ao ser extirpado, deixa de infectar. Adelmo diz que 
isso reduz o conceito de forma de conhecimento, tornando-o vulgar e pragmático, já que não produz nenhum pensar sobre suas contradições.

Afirma que, "na sociedade, não importa o aspecto quantitativo da informação para que ela seja eficaz e significativa. Interessa antes, que ela esteja vinculada aos processos fundamentais e suas contradições" (p.81). Na verdade, Genro Filho insiste na manutenção da idéia de práxis, alegando que ela não pode ser abandonada pela simples informação. Entende que a práxis representa o caminhar humano, a sua historicidade, e a informação apenas remete à manipulação. O que ele acredita é que a questão essencial dos meios de comunicação de massa passa pelo domínio político desses meios pelas organizações revolucionárias. Em nenhum momento se desvincula do sonho de criar a nova sociedade. Não se trata de o jornalismo ser o condutor dessa luta, mas, diferentemente de outros autores, ele antevê, no processo de divulgação de notícias, uma possibilidade de forjar uma nova consciência a partir das contradições intrínsecas ao próprio jornalismo. Para Genro Filho, as possibilidades de manipulação dos meios de comunicação de massa são tantas quanto as de revolução. Resta saber como vão ser pensados esses meios e quem os domina.
A linha de pensamento ancorada na Escola de Frankfurt também sofre a sua crítica, por ter um caráter unilateral. Diz que Adorno via o jornalismo como algo reduzido a simples mercadoria, com conteúdo alienado e alienador, e é a partir daí que critica sua ontologia negativa, afirmando que a crítica, por mais ampla e profunda que seja, se não contém um momento concretamente afirmativo, torna-se diletante e não revolucionária. Alerta que a idéia de indústria cultural não leva em conta as potencialidades da técnica, absolutiza o papel alienador. A manipulação é considerada quase onipotente, não vê as brechas.

A conclusão que parece se impor é a seguinte: existe um fenômeno cultural peculiar ao capitalismo avançado que exige uma conceituação teórica, seja em termos de 'cultura de massa' ou 'indústria cultural'. No entanto, essa conceituação não pode pretender abranger a totalidade do fenômeno cultural, pois a cultura jamais se deixa submeter integralmente pela categoria mercantil. Se isso pudesse ocorrer, a cultura deixaria de ser uma práxis, e, portanto, deixaria de ser cultura (Genro Filho, 1987, p.104). 
Ano XXI, n 32/33, junho e dezembro/2009

Genro Filho é implacável com o que chama de jornalismo capitalista, mas não deixa de fora a crítica aos países ditos socialistas, nos quais percebe uma prática jornalística que se faz a partir dos mesmos pressupostos do jornalismo burguês. Não aceita a idéia de que o jornalismo deva estar vinculado a determinados interesses de classe, $\mathrm{e}$ tampouco acredita que um mundo socialista possa ser o depositário da verdade. Isso seria exercer a mesma manipulação, tão criticada no jornalismo burguês. Entende que, se o jornalismo é apenas um instrumento da luta de classes, então todo o estudo específico desse tema seria em vão.

Se o jornalismo é apenas um instrumento de afirmação e hegemonia burguesa, no socialismo será, tão somente, 'um instrumento proletário' e, numa sociedade sem classes, não terá razão de existir. Sua concreticidade, para Hudec, está inevitavelmente ligada aos interesses de classe que ele representa: 'o jornalismo não existe numa forma abstrata. É sempre concreto, ligado a uma certa classe social cujos interesses expressa, defende e apóia de um modo mais ou menos preciso'. Essa conclusão do autor pode ser entendida em dois níveis. Se for tomada no sentido de que o jornalismo é apenas um instrumento de luta de classes, teremos como conseqüência que ele será um epifenômeno da ideologia. Seu estudo seria um capítulo da discussão teórica sobre a ideologia, uma das manifestações e luta ideológica. Não haveria possibilidade de uma teoria do jornalismo propriamente dita, já que ele teria de ser explicado em função da luta de classe. (p.147).

Nesse sentido, pensar o jornalismo dessa forma reducionista seria legitimar a manipulação. Para o estudioso, tanto a ideologia da objetividade, que vigora no jornalismo burguês, quanto a ideologia do jornalismo científico, de alguns pensadores socialistas, atuam como reforço da ordem, manipulam e alienam. E é aí que ele encontra espaço para expor seu pensamento que tem, no singular, a categoria central da teoria do jornalismo.

O segredo da pirâmide, de onde emerge a teoria de Genro Filho, é aparentemente simples e óbvio. Tem sua inspiração nas categorias filosóficas do "singular, particular e universal", e bebe na teoria estética de Lukács, que entendia a arte como "uma forma de conhecimento cristalizada no particular". Ele, ao contrário, vai dizer que o jornalismo é uma forma de conhecimento centrada no singular. 
Só que o teórico gaúcho não quer discutir singularidade no reino do senso comum, mas sim no sentido filosófico. Alerta que o jornalismo burguês já se preocupa com a singularidade dos fatos, evitando as generalidades, mas entende que este conceito está reificado pela compreensão espontânea do jornalista, que acaba aceitando implicitamente a ideologia dominante, na medida em que apreende a idéia de singularidade apenas como uma receita técnica, uma regra operativa, sobre a qual ele não reflete. É a idéia do mais importante.

Sua proposta singela é de devolver à pirâmide a sua posição original, com sua base bem fincada no chão. Para ele, a pirâmide invertida pretendeu, esse tempo todo, encarnar uma teoria da notícia, mas é apenas uma hipótese racional de operação. O que importa, a partir da sua teoria, é saber que a notícia não vai do mais importante para o menos importante, e sim do singular para o particular e o universal.

Sempre que um fato se torna notícia jornalística, ele é apreendido pelo ângulo da sua singularidade, mas abrindo um determinado leque de relações que formam o seu contexto particular. É na totalidade dessas relações que se reproduzem os pressupostos ontológicos e ideológicos que direcionam sua apreensão. O que o triangulo eqüilátero quer representar, portanto, não é o conteúdo ideológico da notícia, como se a estrutura jornalística que ele pretende indicar coincidisse, necessariamente, seja com a 'notícia funcional'ao sistema, seja com a 'notícia crítica' em relação a ele. (Genro Filho, 1987, p.192).

Genro Filho vai falar ainda da importância do lead, o qual não joga fora junto com a água do banho. "O lead funciona como um organizador da singularidade, mas não precisa estar no começo" (p.196). Ele deixa claro que essa técnica é uma importante conquista da informação jornalística e que acaba sendo um epicentro para a compreensão do todo.

Ao fim, fala da especificidade da reportagem no mundo do jornalismo. Para ele, é justamente aí o momento em que o jornalismo se aproxima da arte, caminhando mais para a particularidade do que para a singularidade. Pensa que a singularidade não é capaz de dar conta da narrativa de uma reportagem e o típico (particular) é o elemento que vai servir como instrumento para a dramatização do acontecimento e a revelação mais explícita - não apenas insinuada - 
Ano XXI, n 32/33, junho e dezembro/2009

do conteúdo universal. Esse talvez seja - no nosso ponto de vista - um dos seus enganos. A singularidade parece ser o que mais dá conta da reportagem, coisa que se pode perceber na prática. No caso do tema em questão, o esporte é um dos espaços do jornalismo que mais se utiliza deste elemento ao salientar histórias de vida, por exemplo, sempre dentro da linguagem emocional que toca no subjetivo do ser humano e trabalha de forma muito eficaz a mais-valia ideológica.

O segredo desvendado por Genro Filho é a teoria que vai iluminar a caminhada de alguns jornalistas desde a década de 80 . Mas é bom que fique claro que é uma caminhada feita por poucos. Considerado maldito na academia, o pensador gaúcho só vai alavancar novos pensares na década de 90 , quando já não está mais presente fisicamente. Aos 36 anos, Adelmo Genro Filho morre em Florianópolis, em 1988, deixando uma vereda aberta na teoria do jornalismo, ainda repleta de mistérios e outros segredos a desvendar. Para ele, o veneno ainda é o melhor antídoto do veneno, o que significa que o jornalismo só pode ser vencido pelo jornalismo.

Genro Filho não deixa muito claro, na sua teoria, mas em muitos momentos intui que o grande segredo está justamente na idéia de que não há, nem pode haver, universalidade, se não houver primeiro singularidade. $\mathrm{O}$ conceito de universalidade, tão falado, discutido e controvertido, na verdade não pode ser conceituado de forma totalizante. Ele só se concretiza a partir do singular. "É na face aguda do singular e nas feições pálidas do particular que o universal se mostra como alusões e imagens que se dissolvem antes de se formarem" (p.140). Ele, assim, propõe um jornalismo que parta do singular, e é neste atalho que, talvez, tenhamos de caminhar. Se, na contemporaneidade, a informação pode ser produzida por qualquer um, a partir de uma página da Internet, por exemplo, e se o jornalismo ainda quer continuar existindo, talvez a única forma de garantir que o jornalismo não desapareça seja sair da mediocridade da mera informação, da simples resposta às seis perguntas básicas de Kiplling. Seguir as pegadas de Genro Filho, narrando o mundo em profundidade, com conseqüência, com historicidade, no caminho de uma sociedade diferente. É importante diferenciar as coisas, informação é produzida por qualquer um, jornalismo requer algo mais e, fundamentalmente, conforme Genro Filho, precisa dizer mais do que o sentido denotativo das palavras. Precisa aspirar à universalidade. 
Um fato dado, narrado a partir de sua singularidade, concretizará nele a universalidade necessária para incomodar o leitor/espectador/ ouvinte. Nesse sentido, concordamos com o autor, entendendo que jornalismo só é jornalismo quando consegue provocar reação, não apenas no nível da emoção, mas a reação necessária para gestar a dúvida, o desconforto, o que leva o ser humano a se perguntar: por que tem de ser assim? E o que podemos fazer para mudar isso?

O certo é que a sociedade sonhada por Genro Filho ainda não vingou. O capitalismo segue hegemônico no mundo todo e, apesar de suas freqüentes crises, mantém-se impávido e forte, constituindo-se como a única grande narrativa, cada vez mais amalgamada pelo comando da grande mídia. Sob o manto do pós-tudo, é o jornalismo que passa a ser anunciado como mais um artigo em extinção. E é a própria mecânica capitalista que está se encarregando de tentar matar o jornalismo, talvez ciente, enfim, do potencial revolucionário e utópico que ele pode carregar. Basta se ver a decisão do Superior Tribunal Federal que extinguiu a exigência do diploma de curso superior para o exercício desta profissão.

Entendemos, amparados em Genro Filho, que discutir a validade do jornalismo no mun- do atual não é saudosismo, nem tentativa desesperada de salvar o que já agoniza. É, isto sim, insuflar a certeza de que há nele esse potencial revolucionário e transformador ainda não explorado na sua totalidade. Se outras formas de narrar a vida estão sendo criadas nos novos tempos, nada impede que esgotemos todas as possibilidades ainda não trabalhadas, ou que essas novas formas sejam impregnadas, também, de suas potencialidades revolucionárias.

No que diz respeito ao jornalismo praticado nos programas de esporte e mesmo quando nos noticiários se referem a questões esportivas, como já abordamos no início deste texto, o que mais se vê é a proposta de uma prática que se utiliza que quase todas as estratégias já descritas por Chomski, como a distração, a gradação, a linguagem bestializadora, o aspecto emocional e o reforço da ignorância. É um jornalismo totalmente ligado ao status quo, chegando ao ponto de se transformar em mera propaganda do sistema, uma vez que é totalmente desvestido de crítica e historicidade. Nesse sentido, o jornalismo, feito à maneira ensinada por Adelmo - com o qual conspiramos - pode levar o público à compreensão da realidade, pode incentivar a construção da soberania comunicacional e, consequentemente, acabar com a 
Ano XXI, n 32/33, junho e dezembro/2009

produção de mais-valia ideológica. A informação e o conhecimento precisam ser libertadores. Ou isso, ou nada mais são do que ideologia. A seguir se praticando este jornalismo transfigurado em propaganda, como o que é feito hoje nos meios de comunicação comerciais, o que se esconde por trás da Copa do Mundo no Brasil em 2014 ainda está longe de ser desvelado. Há que se mudar o jornalista, porque o jornalismo, conceitualmente, só o é se historicizado e contextualizado.

\section{REFERÊNCIAS}

CHOMSKI, Noam. 10 estratégias de manipulação da mídia. Artigo publicado no blog Controvérsia, disponível em < http://blog.controversia.com. br/2010/07/31/chomsky-e-as10-estratgias-de-manipulaomiditica/ $>$. Acesso em 10 de agosto de 2010.

GENRO FILHO, Adelmo. O Segredo da Pirâmide. Para uma teoria marxista do jornalismo. Por Alegre: Tchê, 1987

OURIQUES, Nilso. A Miséria do Esporte. Reflexões sobre as políticas públicas em Santa Catarina. Florianópolis: Insular, 2010

MARINI, Ruy Mauro. El estado de contrainsurgencia. Artigo publicado na página da Universidade Nacional Autónoma do México, que trata sobre a vida e obra do autor, no endereço, < http://www.marini-escritos. unam.mx/016_contrainsurgencia_ es.htm $>$. Acesso em 05 de agosto de 2010.

SILVEIRA, Mauro César. A Batalha de Papel - A guerra do Paraguai através da caricatura. LPM Editores: Porto Alegre, 1996

SILVA, Ludovico. La plus valia ideológica. Universidad Central da Venezuela: Caracas, 1977

Recebido: Julho/2010 Aceito: Agosto/2010 